\title{
The Effectiveness of Low-Level Laser Therapy in Pain Induced by Orthodontic Separator Placement: A Systematic Review
}

\author{
Arash Farzan $^{(\mathbb{D}}$, Katayoon Khaleghi ${ }^{*}$ \\ 'Department of Orthodontics, School of dentistry, Zanjan University of Medical Sciences, Zanjan, Iran \\ ${ }^{2}$ Dental student, Students' Research office, Zanjan University of Medical Sciences, Zanjan, Iran
}

\section{*Correspondence to Katayoon Khaleghi, Dental student, Students Research office, Zanjan University of Medical Sciences, Zanjan, Iran \\ Email: katayoon_khaleghi@ yahoo.com}

Received: December 18, 2020 Accepted: January 6, 2021 epublished: June 24, 2021

\begin{abstract}
Introduction: This systematic review was conducted to evaluate the effectiveness of low-level laser therapy (LLLT) in orthodontic separator pain.

Methods: This article was written according to the Preferred Reporting Items for Systematic Reviews and Meta-Analyses (PRISMA) checklist. Electronically and manually 3 databases, namely PubMed, Scopus and Google Scholar, were searched by the keywords that were selected based on population, intervention, comparison and outcome (PICO) on October 10, 2020. Studies were appraised by Cochrane version 5.2.0 with 7 domains and were checked by these inclusion criteria: 1. Randomized clinical trial (RCT) that examined the efficacy of LLLT in separator pain, 2. Splitmouth design, 3. LLLT application in the first hours after separator placement, 4. LLLT application to both sides of the teeth, 5 . Patients receiving elastomeric separators between the premolars and molars, 6. Lasers with a wavelength of 800-899 nm, 7. Studies conducted from 2010 to 2020, and 8. Participants who went through orthodontic treatment without limitation in gender, age and socialeconomic status.

Results: 299 studies were screened. 34 full-text papers were read by 2 authors independently. In the end, 4 articles met the inclusion criteria. All 4 articles showed LLLT has a significant impact on pain reduction.

Conclusion: The exact protocol for laser therapy is still not clear. Therefore, more studies with a meticulously designed method are needed.

Keywords: Low-level light therapy; Elastomeric separator; Pain.
\end{abstract}

\section{Introduction}

Some orthodontic procedures like having elastomeric separators in place are associated with pain..$^{1-3}$ It has been stated that orthodontic pain has a negative impact on patients' quality of life. ${ }^{1,4}$ Thus, good pain management plays a key role in patient satisfaction with treatment and leads to better cooperation with the doctor. ${ }^{5-7}$

The aim of using separators which are most commonly placed between the second premolars, first and second molars is to make the placement of orthodontic bands simpler. ${ }^{8}$ The placement of separators is tightly associated with pain and discomfort. ${ }^{9}$ As some patients report, this is the most painful part of the entire treatment. ${ }^{8}$ It has been reported in several studies that the highest level of pain is experienced on the second day following orthodontic separator placement, and it decreases gradually in a 7-day period. ${ }^{3}$ Several methods are used to manage discomfort:

Among several methods currently available, oral analgesics, especially the non-steroidal anti-inflammatory drugs (NSAIDs) and bite wafers, are frequently prescribed by orthodontists. ${ }^{4-6}$

There are still some concerns regarding the delaying effect of employing NSAIDs on tooth movement orally or topically. ${ }^{7,8}$ Low-level laser therapy (LLLT) has been widely adopted for the management of acute and chronic pain in various conditions. ${ }^{1,9,10}$ In recent years, several studies have been conducted on LLLT employment to manage orthodontic pain including the pain following separator placement. ${ }^{2}$

The method of laser application, dosage, wavelength and other laser parameters were extensively varied. ${ }^{11}$ Therefore, this study aimed to systematically review "the effect of LLLT on the pain induced by orthodontic separator placement" in which the wavelengths are the same $(830 \mathrm{~nm})$ and the methods are as much as possible similar to each other.

\section{Methods}

This Systematic review is written using the PRISMA checklist and articles were evaluated by the Cochrane 
guideline. The inclusion and exclusion criteria are presented below respectively:

\section{Inclusion Criteria}

(1) Randomized clinical trial (RCT) that examined the efficacy of LLLT in separator pain, (2) Split-mouth design, (3) applying LLLT in the first hours after separator placement, (4) Application of LLLT on both sides of the teeth, (5) patients receiving elastomeric separators between the premolars or molars, (6) Lasers with wavelengths of 800-899 nm, (7) Studies conducted from 2010 to 2020, (8) Participants undergoing orthodontic treatment without selection limitation in gender, age and social-economic status.

\section{Exclusion Criteria}

(1) Animal or in-vitro studies, (2) The literature characterized based on review articles, case reports, descriptive studies, abstracts, systematic reviews and meta-analysis, preliminary clinical studies, and controlled clinical trials.

An automated systematic literature search was conducted using two important databases: PubMed and Scopus; the additional manual search was done on Google Scholar. The search contained only English articles with no restrictions on the publication date.

The search strategy was formulated based on PICO instructions and the used keywords are presented in Table 1. Also, the full electronic search strategy for PubMed is shown in Table 2 with 84 results.

P: Population: patients who need separator placement

I: Intervention: LLLT therapy

O: Outcome: reduction in orthodontic pain
84 articles were found by the PubMed search, 234 additional articles were searched by the Scopus database, and 56 more articles were added by a manual search in Google Scholar.

All 374 collected papers were organized in Endnote software version $\mathrm{X} 8$.

141 duplicated articles were found and after deleting 75 articles, the screening process of 299 articles was started by 2 authors together. At the end of the screening, 17 more duplicates were deleted, and finally, 26 articles were selected as the most relevant studies and 8 articles needed more data for decision-making.

The full text of 34 articles was read by 2 authors independently. Four articles that met the inclusion criteria were selected with the consent of both authors.

Table 2. The Exact Search Strategy for PubMed on October 10, 2020

\begin{tabular}{|c|c|}
\hline PubMed & Search Strategy \\
\hline$\# 1$ & or between all keywords for $\mathrm{P}$ in title/abstract \\
\hline$\# 2$ & $\begin{array}{l}\text { or between all keywords for I in title/abstract }+3 \\
\text { keywords in } \mathrm{MeSH} \text { term }\end{array}$ \\
\hline$\# 3$ & $\begin{array}{l}\text { or between all keywords for } \mathrm{O} \text { in title/abstract }+1 \text { in } \\
\mathrm{MeSH} \text { term }\end{array}$ \\
\hline$\# 4$ & $\begin{array}{l}\text { clinical trial[MeSH Terms]) OR "randomized clinical } \\
\text { trial*"OR randomized OR randomized OR clinical } \\
\text { trial OR cross_over OR split_mouth }\end{array}$ \\
\hline$\# 5$ & $\begin{array}{l}\text { animal* OR mice OR rat OR rats OR mouse OR in } \\
\text { vitro OR in_vitro }\end{array}$ \\
\hline$\# 6$ & AND $\# 2$ AND $\# 3$ AND \#4 \\
\hline$\# 7$ & NOT \#7 \\
\hline
\end{tabular}

Table 1. Keywords Used for Searching in Both PubMed and Scopus Databases

\begin{tabular}{|c|c|c|}
\hline $\mathbf{P}$ & I & $\mathbf{O}$ \\
\hline $\begin{array}{l}\text { separator* } \\
\text { orthodontic treatment } \\
\text { separator placement } \\
\text { elastomeric separator } \\
\text { elastic separators } \\
\text { "banded orthodontic appliances" } \\
\text { band } \\
\text { "orthodontic procedure" } \\
\text { "initial arch wire" } \\
\text { "early orthodontic treatment" } \\
\text { separation } \\
\text { "fixed appliances" } \\
\text { "orthodontic forces" } \\
\text { "separator placement" }\end{array}$ & $\begin{array}{l}\text { Low-level light therapy } \\
\text { laser therapy } \\
\text { laser phototherapy } \\
\text { "low-level laser therapy" } \\
\text { Low-level laser } \\
\text { "low-output laser" } \\
\text { "low-intensity laser" } \\
\text { soft laser } \\
\text { "laser irradiation" } \\
\text { gaas } \\
\text { algaas } \\
\text { LLLT } \\
\text { laser* } \\
\text { "low-power" } \\
\text { "low-therapy" } \\
\text { "light-emitting diode" } \\
\text { diode lasers } \\
\text { "laser energy values" } \\
\text { MeSH terms for Pubmed: } \\
\text { Low-level light therapy } \\
\text { Laser therapy } \\
\text { Laser phototherapy }\end{array}$ & $\begin{array}{l}\text { "orthodontic pain" } \\
\text { orthodontic* } \\
\text { pain } \\
\text { discomfort } \\
\text { toothache } \\
\text { "facial pain" } \\
\text { pain control } \\
\text { "pain management" } \\
\text { "laser irradiation" } \\
\text { "pain perception" } \\
\text { "separator pain" } \\
\text { MeSH terms for Pubmed : } \\
\text { Pain }\end{array}$ \\
\hline
\end{tabular}




\section{Assessment of Risk of Bias}

The studies were categorized into one of the 3 groups ('low', 'unclear' and 'high') with the Cochrane handbook version 5.2.0. Each article was appraised with 7 domains.

\section{Extraction of Data}

The following information was dragged from the included studies: general information of the study and methodology including first author, year, country, blinding, randomization, sample size, mean age, patient loss, data about the questionnaire, statistical analysis, peak time for pain and laser features which are presented in Tables 3 and 4.

\section{Results}

\section{Search Results}

According to the search strategy and after the elimination of the duplicates, 299 articles were screened and after reading the full text, 4 RCTs were selected for their result assessment. The whole selection process based on the PRISMA diagram is shown in Figure 1.

Based on the Cochrane criteria for the overall risk of assessment that is talked about in the Cochrane handbook version 5.2.0 in chapter 8 , articles require to be judged to evaluate the importance of each criterion. The assessment of the articles showed that less attention has been paid to the blinding criterion, particularly the blinding of outcome assessment. Clinical trials should pay more attention to the subject of allocation. Figure 2 presents the data on the risk of bias in each study.

Almallah et al reported that the pain caused by elastomeric separators started after one hour in $63.89 \%$ of patients. According to their results, $11.11 \%$ of patients never experienced pain during the whole period of assessment. There were also statistically significant differences between the experimental and the placebo

Table 3. General Information About Articles and Their Methodology

\begin{tabular}{|c|c|c|c|c|c|c|c|c|c|c|c|}
\hline First Author & Year & Country & $\begin{array}{l}\text { Patient } \\
\text { Num }\end{array}$ & $\begin{array}{l}\text { Mean } \\
\text { Age }\end{array}$ & $\begin{array}{l}\text { Lost } \\
\text { Patient }\end{array}$ & $\begin{array}{l}\text { Study } \\
\text { Design }\end{array}$ & Blindness & VAS & $\begin{array}{l}\text { Questionnaire } \\
\text { Time }\end{array}$ & Peak Pain & $\begin{array}{l}\text { Statistical } \\
\text { Analysis }\end{array}$ \\
\hline Artés-Ribas & 2013 & Spain & 20 & 26.4 & 0 & $\begin{array}{l}\text { Split- } \\
\text { mouth }\end{array}$ & Single blind & 10 & $\begin{array}{l}\text { T1, before } \\
\text { placing the } \\
\text { separator; T2, } \\
5 \text { min after } \\
\text { placement and } \\
\text { laser applied, } \\
6 \mathrm{~h}, 24 \mathrm{~h}, 48 \\
\mathrm{~h}, \text { and, } 72 \mathrm{~h} \\
\text { after separator } \\
\text { placement }\end{array}$ & $\begin{array}{l}6 \text { and } 24 \mathrm{~h} \\
\text { (T3-T4) }\end{array}$ & $\begin{array}{c}\text { Microsoft } \\
\text { Excel, } \\
\text { Statgraphics } \mathbb{} \\
\text { Plus, } \\
\text { Multivariate } \\
\text { analysis }\end{array}$ \\
\hline Almallah & 2020 & Syria & 36 & 17.44 & $\begin{array}{c}\text { Not } \\
\text { mentioned }\end{array}$ & $\begin{array}{l}\text { Split- } \\
\text { mouth }\end{array}$ & $\begin{array}{l}\text { Double } \\
\text { blind }\end{array}$ & 10 & $\begin{array}{c}1,6,24,48 \\
\text { and } 96 \text { h after } \\
\text { separation }\end{array}$ & $24 \mathrm{~h}$ & $\begin{array}{c}\text { Microsoft } \mathbb{} \\
\text { Excel, } \\
\text { Minitab, v. } \\
17 \text { and IBM } \\
\text { SPSS, } t \text { tests, } \\
\text { ANOVA, LSD }\end{array}$ \\
\hline Eslamian & 2014 & Iran & 37 & 24.97 & $\begin{array}{l}\text { Not } \\
\text { mentioned }\end{array}$ & $\begin{array}{l}\text { Split- } \\
\text { mouth }\end{array}$ & Single blind & 10 & $\begin{array}{c}\text { (hour 0, } \\
\text { before laser } \\
\text { irradiation); after } \\
6,24 \text {, and } 30 \text { h; } \\
\text { and on the days } \\
3,4,5,6 \text {, and } 7\end{array}$ & 6 and $30 \mathrm{~h}$ & $\begin{array}{l}\text { (SPSS17, the } \\
\text { mean and } \\
\text { standard } \\
\text { deviation } \\
\text { of the VAS } \\
\text { scores, } \\
\text { Wilcoxon's } \\
\text { signed-rank } \\
\text { test, Mann- } \\
\text { Whitney } \\
\text { U test, } \\
\text { Friedman's } \\
\text { test }\end{array}$ \\
\hline Almallah & 2016 & Syria & 36 & 18.4 & $\begin{array}{c}\text { Not } \\
\text { mentioned }\end{array}$ & $\begin{array}{l}\text { Split- } \\
\text { mouth }\end{array}$ & $\begin{array}{c}\text { Not } \\
\text { mentioned }\end{array}$ & 10 & $\begin{array}{c}1,6,24,48 \\
96 \text { hours after } \\
\text { separation. }\end{array}$ & $\begin{array}{c}\text { Single } \\
\text { irradiation: } \\
\text { 4h double } \\
\text { irradiation: } \\
48 \mathrm{~h}\end{array}$ & $\begin{array}{c}\text { Microsoft } \\
\text { Excel, } \\
\text { Minitab }{ }^{\circledR} \\
\text { V17, } \\
\text { SPSS®V17, } \\
\text { t-test. } \\
\text { ANOVA, LSD }\end{array}$ \\
\hline
\end{tabular}


Table 4. Laser Features

\begin{tabular}{|c|c|c|c|c|c|c|c|c|}
\hline First Author & $\begin{array}{c}\text { Laser } \\
\text { Wavelength } \\
(\mathrm{nm})\end{array}$ & $\begin{array}{l}\text { Power } \\
(\mathrm{mW})\end{array}$ & $\begin{array}{c}\text { Other } \\
\text { Parameters }\end{array}$ & $\begin{array}{c}\text { Time of } \\
\text { Irradiation (s) }\end{array}$ & $\begin{array}{c}\text { Site of } \\
\text { Irradiation }\end{array}$ & Placebo Laser & Operator & Jaw \\
\hline Artés-Ribas & 830 & 100 & $\begin{array}{c}\text { Diameter }=7 \\
6 \mathrm{~J} / \mathrm{cm}^{2} \\
\text { GaAlAs }\end{array}$ & 20 & $\begin{array}{l}3 \text { Buccal } \\
3 \text { Lingual }\end{array}$ & $\begin{array}{l}\text { Polymerizing light with a } \\
\text { similar fiber diameter of } \\
0.7 \mathrm{~cm} \text {, and emitted the } \\
\text { same whistle sound that a } \\
\text { laser emits to reproduce the } \\
\text { exact condition }\end{array}$ & $\begin{array}{l}\text { Single } \\
\text { operator }\end{array}$ & Just maxilla \\
\hline $\begin{array}{l}\text { Almallah } \\
2020\end{array}$ & 830 & 100 & $\begin{array}{c}\text { Diameter }=7 \\
4 \mathrm{~J} / \mathrm{cm}^{2} \\
\text { GaAlAs }\end{array}$ & 28 & $\begin{array}{l}4 \text { Buccal } \\
4 \text { Lingual }\end{array}$ & $\begin{array}{l}\text { On the placebo side, the } \\
\text { same laser device was used } \\
\text { after the safety cover was } \\
\text { removed so that the device } \\
\text { produced the same sounds, } \\
\text { but no irradiation occurred }\end{array}$ & $\begin{array}{c}\text { Not } \\
\text { mentioned }\end{array}$ & $\begin{array}{c}30 \\
\text { maxilla } \\
6 \text { mandible }\end{array}$ \\
\hline Eslamian & 810 & 100 & $\begin{array}{l}\text { GaAlAs } \\
2 \mathrm{~J} / \mathrm{cm}^{2}\end{array}$ & 20 & $\begin{array}{l}5 \text { Buccal } \\
5 \text { Lingual }\end{array}$ & No laser irradiation & $\begin{array}{c}\text { Not } \\
\text { mentioned }\end{array}$ & $\begin{array}{c}22 \text { maxilla } \\
15 \\
\text { mandible }\end{array}$ \\
\hline Almallah & 830 & 100 & $\begin{array}{c}\text { Diameter }=7 \\
4 \mathrm{~J} / \mathrm{cm}^{2} \\
\text { GaAlAs }\end{array}$ & 28 & $\begin{array}{l}4 \text { Buccal } \\
4 \text { Lingual }\end{array}$ & $\begin{array}{l}\text { On the placebo side, the } \\
\text { safety cover was removed, } \\
\text { the device was allowed to } \\
\text { give sounds }\end{array}$ & $\begin{array}{c}\text { Not } \\
\text { mentioned }\end{array}$ & $\begin{array}{c}21 \text { maxilla } \\
15 \text { mandible }\end{array}$ \\
\hline
\end{tabular}
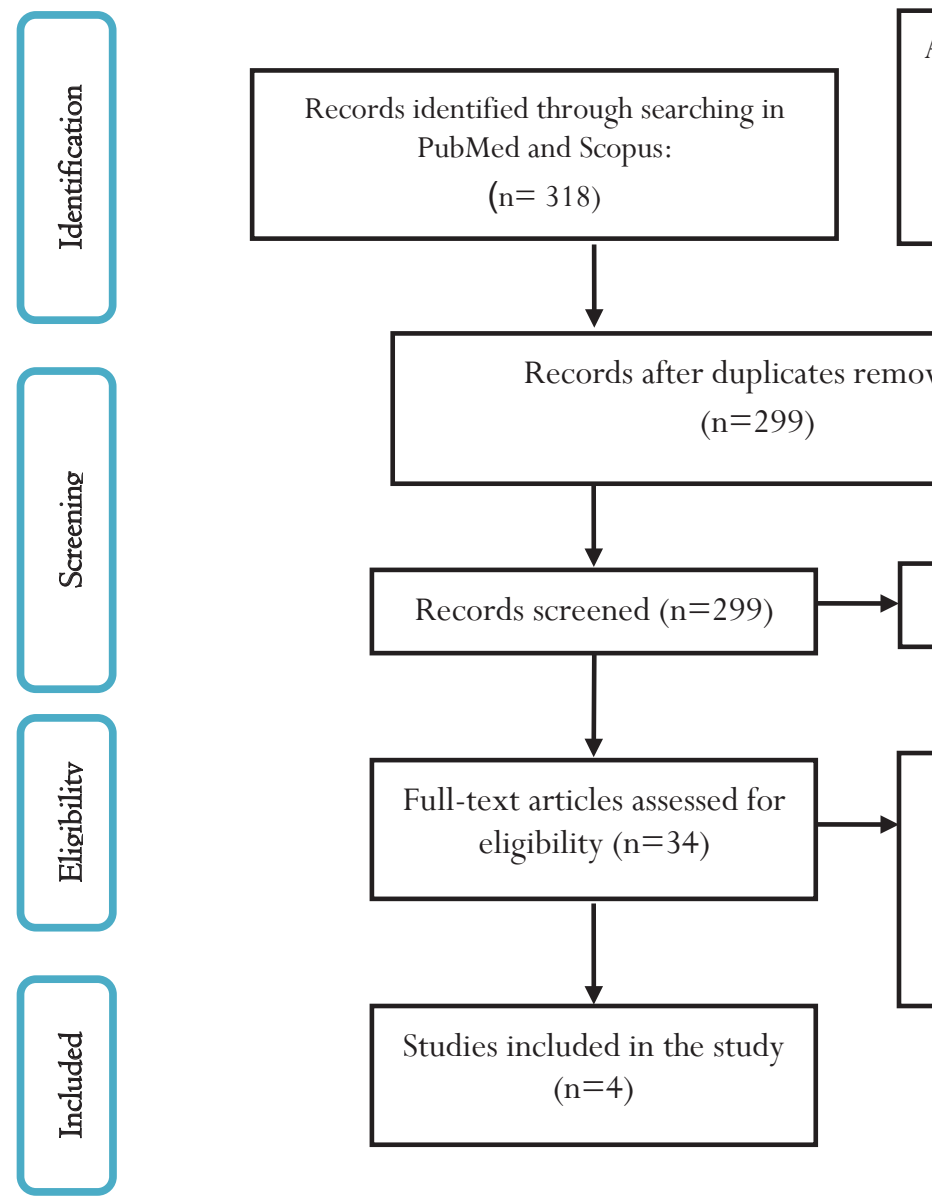

Additional records identified through hand search in Google Scholar:

$$
(n=56)
$$

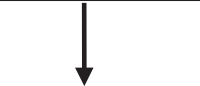

Records excluded $(n=265)$

Full-text articles excluded:

Not related to the separator pain: 11

Not meet the inclusion criteria: 19

Figure 1. Search Strategy According to PRISMA Flowchart. 


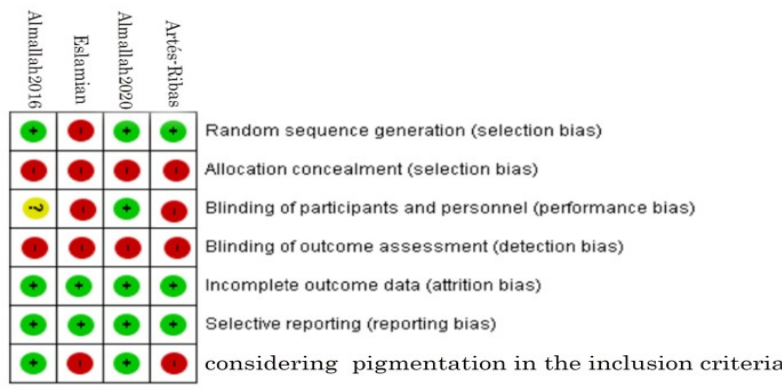

Figure 2. Risk of Bias Graph According to Cochrane Guideline.

sides for both single and double irradiation at 1, 6, 24 and 48 hours $(P=0.043$ for single and $P=0.026$ for double irradiation for the experimental sides). By comparison of single irradiation with double irradiation, no significant differences between the experimental sides were detected at all assessment times.?

Almallah et al, in 2020, evaluated the effect of LLLT on pain prior to separator placement. The sample population consisted of 36 patients divided into 2 groups: (1) single irradiation and (2) double irradiation. The result showed that the pain perception on 1 or both sides started after 1 hour in 23 patients. Four patients never felt any pain during the treatment. In the singleirradiation group, there was a significant difference in the pain levels between the experimental and placebo sides at 6, 24 and 48 hours after separation $\left(P_{6}=0.005, P_{24}=0.044, P_{48}=0.029\right)$, whereas in the doubleirradiation there was a significant difference in the pain levels at all assessment time points $\left(P_{1}=0.012\right.$, $\left.P_{6}=0.004, P_{24}=0.012, P_{48}=0.002, P_{96}=0.019\right)$. No significant differences were seen between the two groups $\left(P_{1}=0.835\right.$, $\left.P_{6}=0.416, P_{24}=0.420, P_{48}=0.694, P_{96}=0.819\right) .{ }^{12}$

The results of the study by Artés-Ribas et al significantly revealed that the laser-irradiated quadrant was mostly associated with lower pain scores rather than the quadrant exposed to placebo light at all experimental time points. $(P<0.0001) .{ }^{13}$

In 2014, Eslamian et al found a significant difference $(P<0.05)$ in pain perception between the placebo and laser groups at 6,24 , and 30 hours and on day 3 of the experiment. The recorded pain indicated that there was no significant gender difference between the 2 groups. More pain associated with the mandible was recorded $(P$ $<0.05)$ and the pain perception was significantly higher $(P$ $<0.05)$ in the age group of $\geq 18$ years. ${ }^{10}$

\section{Discussion}

In this systematic review, we analyzed 4 randomized splitmouth clinical trials to evaluate the efficacy of LLLT with wavelengths of $800-890 \mathrm{~nm}$ in orthodontic separator pain. In general, there were three major factors influencing the weakness of the existing evidence: study methodology, individual variation, and laser dosimetry. ${ }^{1}$

\section{Study Methodology}

After scrutinizing 34 full-text articles, 23 articles were selected in all of which RCTs were studied based on the effectiveness of LLLT in separator pain. Out of these 23 articles, 11 articles had a split-mouth design, ${ }^{7,8,10,12-19} 1$ of them designed as cross over study (2), and 11 remaining articles have been conducted by recruiting a parallelgroup. .,20-29 $^{2}$

The split-mouth technique is a popular design in oral health research associated with the advantage of reducing the effect of the inter-person variability of pain perception. ${ }^{13,24}$ This method is very well suited for the study of pain perception. ${ }^{1,11,13}$ According to the recommendations by Lesaffre et al and the Cochrane Oral Health group, split-mouth and parallel-arm studies should be assessed separately., ${ }^{1,30-32}$

Another difference in the study methodology is related to laser protocol irradiation. ${ }^{7,12}$

Among the reviewed papers, 2 of them have compared single irradiation with double irradiation. One study has checked just double irradiation and the other one has assessed single irradiation. All 4 articles concluded that irradiation of LLLT could effectively reduce the pain in comparison with the placebo. ${ }^{7,10,12,13}$ Moreover, 3 studies have focused on double irradiation. Eslamian et al and Almallah applied the laser immediately and 24 hours after separator placement. ${ }^{7,10}$ Almallah et al in their study assessed the laser as pre-treatment (1 hour before and immediately after separator placement). ${ }^{12}$ In all 3 articles, double irradiation was effective in the reduction of pain perception, but it had no advantage over single irradiation.

Questionnaire completion time is another different point among articles.

Initial pain and also peak time pain vary among the conducted studies. Artés-Ribas et al reported that pain started after 5 minutes and Eslamian et al showed that pain began immediately. However, it started after 1 hour for most of the patients in the studies by Almallah et al.,12 Hence, in order to achieve the best result with desirable effectiveness in laser treatment, it is better to begin treatment early.

The peak pain intensity is reported to occur 30 hours after the placement of elastomeric separators in both groups in Eslamian and colleagues' study. ${ }^{10}$

Similar to Almallah et al who showed peak pain time at 24 hours, Artés-Ribas et al reported the maximum pain at 6-24 hours. Setting the time intervals with these critical time points would help the authors not to miss any important data as well as helping the researcher to compare the results of the studies more easily. ${ }^{7,13}$

\section{Individual Variation}

Because of the subjective nature of pain, using the visual analog scale (VAS) as a method of pain measurement is 
recommended in the articles. The VAS has been reviewed extensively and has been found to be a reliable method. ${ }^{33,34}$ All 4 articles employed a 0-10 VAS for their pain intensity measurement.

Experiences of pain can be affected by culture; some ethnic groups are often expected to conveniently express their pain experience. ${ }^{10}$ Split-mouth design is a way for reducing inter-person variability.

\section{Laser Dosimetry}

The selection of the right dose is an important element that should be taken into account to reach an ideal result. ${ }^{7,10}$ The dosage makes the treatment more effective when it is lower than $20 \mathrm{~J} / \mathrm{cm}^{2}$ per area and $5 \mathrm{~J} / \mathrm{cm}^{2}$ per point. $7,10,12,17,27$ Laser penetration to tissues is directly related to its wavelength, ${ }^{26}$ thus, comparing and assessing the articles with different wavelengths could not shed new light on these cases and the results might be unreliable. In some studies, GaAlAs $830 \mathrm{~nm}$ is considered to be superior in tissue penetration than other lasers, and it has exhibited an advanced analgesic effect which is documented in clinical and laboratory studies. ${ }^{12,13,21}$

The wavelength size in 15 articles was in the range of $800 \mathrm{~nm}, 4$ articles were in the range of $600 \mathrm{~nm}$, and 6 of them were at $\geq 900 \mathrm{~nm}$. The amount of wavelengths in 3 of 4 articles reviewed in this study was at $830 \mathrm{~nm}$ and 1 of 4 was at $810 \mathrm{~nm}$. Another issue is the difference in the irradiation area and dose of irradiation among the articles. Some studies applied the laser over the buccal and lingual sides of the teeth and some applied it over only one side. According to RCTs, the frequency of irradiation points varied between 1 to 10 times for each area. By increasing the dose and number of the irradiation area, the total energy of the laser increases proportionally and can affect the laser penetration and ultimately the pain reduction.

All four articles have been irradiated on both sides of the teeth (buccal and palatal). Still, the irradiation frequency was different from that of Artés-Ribas et al up to 6 times. They applied LLLT on mesial, distal and apical of the exact tooth. Our results also varied up to eight numbers of applications from Almallah et al study (mesial and distal of the first molar, distal of the second premolar, and mesial of the second molar) and also up to ten times difference compared to Eslamian and colleagues study that applied the LLLT on distal and mesial of the second premolars and first permanent molars, as well as applying on the distal of second permanent molars.

\section{Conclusion}

Applying the laser protocol which was employed in 4 articles can be considered as an effective method in reducing separator pain. Using a laser with wavelengths of 810 and $830 \mathrm{~nm}$, powered by $100 \mathrm{mw}$ when applied to both sides of the teeth, is an effective approach to pain reduction. Since all 4 studies stated that LLLT with the lowest dose is a potential tool in reducing pain, as a conclusion of reviewing the four articles, it can be stated that for applying the minimum laser energy, the following laser application features are proposed: wavelength of $810 \mathrm{~nm}, 100 \mathrm{MW}, 20$ seconds, six times for each tooth, buccally and lingually. Furthermore, the results also indicated that single irradiation is adequate for pain reduction. There are still some challenges with regard to the superiority of laser irradiation before or after separator placement and additional information to clarify this issue is required. While many articles have been written on lasers, the best protocol for laser therapy is still not available. The effectiveness of pain reduction caused by separator placement by a laser is still in its infancy. Thus, it is recommended to design articles with more organization. This review aims at providing future strategies and guidance for upcoming researches to reduce pain caused by separator placement with the aid of LLLT.

\section{References}

1. Ren C, McGrath C, Yang Y. The effectiveness of low-level diode laser therapy on orthodontic pain management: a systematic review and meta-analysis. Lasers Med Sci. 2015;30(7):1881-93. doi:10.1007/s10103-015-1743-4

2. Martins IP, Martins RP, Caldas SGFR, dos Santos-Pinto A, Buschang PH, Pretel H. Low-level laser therapy $(830 \mathrm{~nm})$ on orthodontic pain: blinded randomized clinical trial. Lasers Med Sci. 2019;34(2):281-6. doi:10.1007/s10103018-2583-9

3. Ortega SM, Gonçalves MLL, Da Silva T, Horliana ACRT, Motta LJ, Altavista OM, et al. Evaluation of the use of photobiomodulation following the placement of elastomeric separators: Protocol for a randomized controlled clinical trial. Medicine (United States). 2019;98(43). doi:10.1097/ md.0000000000017325

4. Eslamian L, Dehghani F, Amraie H. Comparison of Ketoprofen Gum and Ketoprofen Gel for Pain Relief after Activation of Orthodontic Appliances. J Islam Dent Assoc Iran. 2016;28(4):142-8. doi:10.30699/jidai.29.4.142

5. Eslamian L, Youssefinia S, Ameli N. Efficacy of Ketoprofen and Benzocaine Chewing Gums for Reducing Orthodontic Pain. J Islam Dent Assoc Iran. 2014;26(4):218-24.

6. Patel D, Mubeen S, Taylor N. Separators: a review of uses and limitations. Ortho Update. 2018;11(2):61-6. doi:10.12968/ortu.2018.11.2.61

7. Almallah MM, Almahdi WH, Hajeer MY. Evaluation of low level laser therapy on pain perception following orthodontic elastomeric separation: a randomized controlled trial. J Clin Diagn Res. 2016;10(11): ZC23. doi:10.7860/jcdr/2016/22813.8804

8. Farias RD, Motta RH. Low-level laser therapy for controlling pain in orthodontic patients during the use of elastic separators: randomized clinical trial. Laser Phys Lett. 2018;15(9):095602. doi:10.1088/1612-202x/aad1c1

9. Borzabadi-Farahani A, Cronshaw M. Lasers in orthodontics. Lasers in Dentistry-Current Concepts. Springer; 2017. p. 247-71. doi:10.1007/978-3-319-519449_12 
10. Eslamian L, Borzabadi-Farahani A, Hassanzadeh-Azhiri A, Badiee MR, Fekrazad R. The effect of 810-nm low-level laser therapy on pain caused by orthodontic elastomeric separators. Lasers Med Sci. 2014;29(2):559-64. doi:10.1007/ s10103-012-1258-1

11. Shi Q, Yang S, Jia F, Xu J. Does low level laser therapy relieve the pain caused by the placement of the orthodontic separators? a meta-analysis. Head Face Med. 2015;11(1):28. doi:10.1186/s13005-015-0085-6

12. Almallah MME, Hajeer MY, Almahdi WH, Burhan AS, Latifeh Y, Madkhaneh SK. Assessment of a single versus double application of low-level laser therapy in pain reduction following orthodontic elastomeric separation: A randomized controlled trial. Dent Med Probl. 2020;57(1):45-52. doi:10.17219/dmp/113332

13. Artés-Ribas M, Arnabat-Dominguez J, Puigdollers A. Analgesic effect of a low-level laser therapy $(830 \mathrm{~nm})$ in early orthodontic treatment. Lasers Med Sci. 2013;28(1):335-41. doi:10.1007/s10103-012-1135-y

14. Qamruddin I, Alam MK, Fida MP, Khan AG. Effect of a single dose of low-level laser therapy on spontaneous and chewing pain caused by elastomeric separators. Am J Orthod Dentofacial Orthop. 2016;149(1):62-6. doi:10.1016/j.ajodo.2015.06.024

15. Abtahi SM, Mousavi SA, Shafaee H, Tanbakuchi B. Effect of low-level laser therapy on dental pain induced by separator force in orthodontic treatment. Dent Res J. 2013;10(5):647. doi:10.4317/jced.51979

16. Ganesh G, Tripathi T, Rai P, Kanase A. Effect of photobiomodulation on pain perception secondary to separator placement. Laser Dent Sci . 2019;3(2):111-7. doi:10.1007/s41547-019-00058-7

17. Arshad F, Dharmesh H, Bharathi V, Ram AA, Begum S. Effect of Two Energy Values of 810-nm Diode LLLT on Reducing Pain Caused by Orthodontic Elastomeric Separators: A Split Mouth Randomized Controlled Clinical Study. Int J Prev Clin Dent Res 2018;5(2):1-4.

18. AlSayed Hasan MMA, Sultan K, Hamadah O. Evaluating low-level laser therapy effect on reducing orthodontic pain using two laser energy values: a split-mouth randomized placebo-controlled trial. Eur J Orthod. 2018;40(1):23-8. doi:10.1093/ejo/cjx013

19. Gupta S, Ahuja S, Bhambri E, Sharma S, Sharma R, Kalia $\mathrm{H}$. Evaluating the effect of low-level laser therapy on pain induced by orthodontic separation: a randomized split-mouth clinical trial. Laser Dent Sci. 2018;2(4):221-8. doi:10.1007/s41547-018-0040-5

20. Nóbrega C, da Silva EMK, de Macedo CR. Low-level laser therapy for treatment of pain associated with orthodontic elastomeric separator placement: a placebo-controlled randomized double-blind clinical trial. Photomed Laser Surg. 2013;31(1):10-6. doi:10.1089/pho.2012.3338

21. Lim HM, Lew KKK, Tay DKL. A clinical investigation of the efficacy of low level laser therapy in reducing orthodontic postadjustment pain. Am J Orthod Dentofacial Orthop. 1995;108(6):614-22. doi:10.1016/s0889-5406(95)70007-2
22. Fujiyama K, Deguchi T, Murakami T, Fujii A, Kushima $\mathrm{K}$, Takano-Yamamoto T. Clinical effect of $\mathrm{CO} 2$ laser in reducing pain in orthodontics. Angle Orthod. 2008;78(2):299-303. doi:10.2319/033007-153.1

23. Figueira IZ, Sousa APC, Machado AW, Habib FAL, Soares LGP, Pinheiro ALB. Clinical study on the efficacy of LED phototherapy for pain control in an orthodontic procedure. Lasers Med Sci. 2019;34(3):479-85. doi:10.1007/s10103018-2617-3

24. Oshagh M, Najafi HZ, Bahramnia F, Gharesi-Fard B. Comparison of the analgesic effect of Ibuprofen and pulsed low-level laser in reducing pain after orthodontic separator placement and evaluation of the changes in the sulcular pain especially prostaglandin E2 level. J Dent Lasers. 2014;8(2):44. doi:10.4103/0976-2868.145137

25. Marini I, Bartolucci ML, Bortolotti F, Innocenti G, Gatto MR, Alessandri Bonetti G. The effect of diode superpulsed low-level laser therapy on experimental orthodontic pain caused by elastomeric separators: a randomized controlled clinical trial. Lasers Med Sci. 2015;30(1):35-41. doi:10.1007/ s10103-013-1345-y

26. Kim WT, Bayome M, Park J-B, Park JH, Baek S-H, Kook Y-A. Effect of frequent laser irradiation on orthodontic pain: a single-blind randomized clinical trial. Angle Orthod. 2013;83(4):611-6. doi:10.2319/082012-665.1

27. Esper MÂLR, Nicolau RA, Arisawa EÂLS. The effect of two phototherapy protocols on pain control in orthodontic procedure-a preliminary clinical study. Lasers Med Sci. 2011;26(5):657-63. doi:10.1007/s10103-011-0938-6

28. Buchwald B. Effects of Low Level Laser Therapy on Orthodontic Pain. Texas A\&M University; 2014. doi:10.1007/978-3-540-29805-2_2223

29. Furquim RD, Pascotto RC, Neto JR, Cardoso JR, Ramos AL. Low-level laser therapy effects on pain perception related to the use of orthodontic elastomeric separators. Dental Press J Orthod. 2015;20(3):37-42. doi:10.1590/21769451.20.3.037-042.oar

30. Stein S, Korbmacher-Steiner H, Popovic N, Braun A. Pain reduced by low-level laser therapy during use of orthodontic separators in early mixed dentition. J Orofac Orthop. 2015;76(5):431-9. doi:10.1007/s00056-015-0306-4

31. Higgins J, Green S. Cochrane handbook for systematic reviews. The cochrane collaboration; 2008. doi:10.1002/9780470712184

32. Lesaffre E, Philstrom B, Needleman I, Worthington $H$. The design and analysis of split-mouth studies: what statisticians and clinicians should know. Stat Med. 2009;28(28):347082. doi:10.1002/sim. 3634

33. Moher D, Liberati A, Tetzlaff J, Altman DG. Preferred reporting items for systematic reviews and meta-analyses: the PRISMA statement. Int J Surg. 2010;8(5):336-41. doi:10.1016/j.ijsu.2010.02.007

34. Topolski F, Moro A, Correr GM, Schimim SC. Optimal management of orthodontic pain. J Pain Res. 2018;11:589. doi:10.2147/jpr.s127945 